\title{
Thomas Kuhn dan Teori Hubungan Internasional: Realisme sebagai Paradigma
}

\author{
Azwar Asrudin \\ The Asrudian Center
}

\begin{abstract}
This writing is the writer's objections against Peter Van Ness' claim on realist paradigm. In reference to Thomas Kuhn's paradigm shift, Van Ness argued that realism, as what Kuhn would call "normal science" in international relations theory, is in a crisis because of its inability to explain some anomalies. According to Van Ness, rampant number of states doing security cooperation is enough to call realism is in a crisis as a paradigm. Through several cases on international anarchy, the writer argues that realism is still relevant and worthy to be called a paradigm in Kuhnian category.
\end{abstract}

Keywords: paradigm, Thomas Kuhn, realism, anarchy, cooperative security

\begin{abstract}
Abstrak
Tulisan ini adalah bantahan penulis atas gugatan Peter Van Ness terhadap paradigma realisme. Dengan merujuk pada karya Thomas Kuhn tentang pergeseran paradigma, Van Ness berargumen bahwa realisme, yang disebut oleh Kuhn sebagai "normal science" dalam teori hubungan internasional, berada dalam krisis karena ketidakmampuannya menjelaskan sejumlah anomali. Menurut Van Ness maraknya kerjasama keamanan yang terjadi antar negara cukup untuk menyebut realisme berada dalam tahap krisis sebagai sebuah paradigma. Penulis menolak argumen Van Ness tersebut. Melalui sejumlah contoh kasus anarki internasional, penulis mengatakan bahwa realisme tetaplah relevan dan layak disebut sebagai paradigma dalam kategori Kuhnian.
\end{abstract}

Kata kunci: paradigma, Thomas Kuhn, realisme, anarki, kerjasama keamanan 


\section{Pendahuluan}

Persoalan besar teoretis dan akademis dalam disiplin Hubungan Internasional (HI) yang masih terus mengemuka hingga saat ini adalah ketidaksepakatan para ilmuwan $\mathrm{HI}$ atas pertanyaan masih relevankah paradigma realisme digunakan untuk memahami masalah-masalah internasional setelah Perang Dingin berakhir.

Dalam artikelnya yang berjudul "No Exit: The Errors of Endism," Samuel Huntington (The National Interest, 1989) mengatakan, di era akhir Perang Dingin (1989) disiplin HI telah mengalami pergeseran paradigma yang sangat signifikan. Jika di masa Perang Dingin paradigma deklinisme begitu mendominasi, di masa setelahnya, paradigma endisme justru lebih mengambil peran. Di era ini, menurut pemahaman paradigma endisme, hal yang menjadi masalah-masalah internasional telah berakhir, bahwa realisme tidak lagi dipandang sebagai paradigma yang paling presisi.

Paradigma endisme itu sendiri menurut Huntington berkembang dalam tiga tingkatan. ${ }^{1}$ Pertama, pada tingkatan yang paling spesifik, endisme mengelu-elukan

${ }^{1}$ Penjelasan setelahnya tentang endisme sepenuhnya mengutip pada tulisan Huntington. Namun pengutipan itu penulis berikan tambahan rujukan sebagai penegasan di dalam bodynote.

2 Dalam ilmu HI, gagasan ini disebut dengan teori perdamaian demokrasi. Teori ini terinspirasi dari gagasan filsuf Jerman Immanuel Kant mengenai perdamaian republikan. Dalam buku tipisnya yang berjudul Perpetual Peace, Kant mengatakan perdamaian abadi hanya bisa terwujud jika negara-negara bangsa memeluk sistem politik republikan.

3 Dalam tulisannya Michael W. Doyle mengatakan, "even though liberal states heve become involved in numerous wars with nonliberal states, constitutionally secure liberal states have yet engage in war with one another." Doyle kemudian melanjutkan dalam catatan kakinya "There appear to be some exceptions to the tendency for berakhirnya Perang Dingin. Pada musim semi 1989 New York Times dan International Institute for Strategic Studies, George Kennan dan George Bush, menyatakan proposisi ini dalam satu dan lain bentuk. Akhir Perang Dingin menjadi Kebenaran Mapan dari Kemapanan Kebijakan Luar Negeri (the Foreign Policy Establishment's Established Truth).

Kedua, endisme menyatakan dirinya dalam proposisi yang lebih akademik dan umum bahwa perang di antara negara-negara bangsa, atau setidaknya di antara negaranegara bangsa jenis tertentu, telah berakhir. Banyak ilmuwan HI yang merujuk pada gagasan mengenai tidak adanya perang di antara negara-negara demokratis (Lihat ulasan Asrudin, 2009: 65-102; Lihat juga Asrudin, 2010: 90-102)2 dalam sejarah dan makin meningkatnya rezim demokratis sejak 1974 sebagai bukti bahwa kemungkinan terjadinya perang sangat kecil. Dalam pernyataan yang berhubungan namun merupakan versi lain dari proposisi ini, Michael Doyle mengatakan bahwa perang mustahil terjadi di antara negara-negara liberal (Doyle, 1983: 213). ${ }^{3}$

liberal states not to engage in a war with each other. Peru and Ecuador, for example, entered into conflict. But for each, the war came within one to three years after the establishment of a liberal regime, that is, before the pacifymg effects of liberalism could become deeply ingrained. The Palestinians and the Israelis clashed frequently along the Lebanese border, which Lebanon could not hold secure from either belligerent. But at the beginning of the 1967 War, Lebanon seems to have sent a flight of its own jets into Israel. The jets were repulsed. Alone among Israel's Arab neighbors, Lebanon engaged in no further hostilities with Israel. Israel's recent attack on the territory of Lebanon was an attack on a country that had already been occupied by Syria (and the P.L.O.). Whether Israel actually will withdraw (if Syria withdraws) and restore an independent Lebanon is yet to be determined." 
Terakhir, adalah tingkatan paradigma endisme yang paling ekstrem. Paradigma ini diajukan oleh Francis Fukuyama dalam sebuah esai yang sangat populer dan kontroversial berjudul "The End of History?" dalam edisi Musim Panas jurnal The National Interest (1989). Dalam esainya itu, Fukuyama bukan saja merayakan akhir Perang Dingin, melainkan juga "akhir sejarah." Era ini, kata Fukuyama, merupakan "kemenangan mutlak tak terbantahkan liberalisme ekonomi dan politik" dan pudarnya pesona sistem-sistem lainnya yang menjadi musuh liberalisme. Fukuyama menegaskan meski di era "akhir sejarah" perang masih mungkin terjadi di antara negara-negara dunia ketiga yang masih terjebak dalam proses sejarah. Namun bagi negara-negara maju, Uni Soviet, dan Cina, sejarah telah berakhir.

Yang menarik adalah pendekatan endisme ini rupanya hingga kini masih dianggap sebagai paradigma yang sangat seksi bagi sebagian ilmuwan HI. Saking seksinya, paradigma endisme ini kembali dimunculkan oleh Peter Van Ness4. Pada tahun 2014, melalui konsep "kerjasama keamanan" untuk mengkritik paradigma realisme. Dengan merujuk pada karya Thomas Kuhn tentang pergeseran paradigma, Van Ness berargumen bahwa realisme, yang disebut oleh Kuhn sebagai "normal science" dalam teori Hubungan Internasional, berada dalam krisis karena ketidakmampuannya menjelaskan sejumlah anomali. Menurut Van Ness semakin maraknya saling ketergantungan ekonomi dan kerjasama keamanan antar negara merupakan indikator penting untuk menyebut realisme sedang berada dalam tahap krisis sebagai sebuah paradigma.

Artikel ini sesungguhnya ditulis untuk memberikan tanggapan kritis atas working paper Van Ness (2014) yang berjudul "Thomas Kuhn and International Relations Theory: Realism in Crisis." Tanggapan kritis ini saya utarakan dengan menyebut sejumlah kasus empiris, dimana meskipun Perang Dingin telah berakhir, negara-negara rupanya masih membingkai dunia dengan cara-cara yang

4 Visiting Fellow, Department of International Relations, School of International, Political \& Strategic Studies, realis. Mereka masih menaruh curiga satu sama lain. Selain itu, penulis juga menambahkan contoh kasus empiris kondisi dunia kekinian yang juga menunjukkan hal yang sama.

Untuk memudahkan ulasan, penulis akan membagi artikel ini berdasarkan urutan bahasan Van Ness. Pertama, penulis akan menjelaskan tentang apa itu paradigma Kuhn. Kedua, akan dijelaskan juga apa itu paradigma realisme. Ketiga, tentang gugatan Van Ness atas paradigma realisme. Keempat, pembelaan realis atas gugatan Van Ness.

\section{Apa itu Paradigma}

Pada tahun 2012, University of Chicago Press menerbitkan sebuah edisi khusus peringatan 50 tahun buku Thomas Kuhn yang sangat berpengaruh, The Structure of Scientific Revolutions. Kuhn yang meninggal karena kanker paru pada tahun 1996, merupakan ahli Fisika di Universitas Harvard dan menjadi terkenal karena karya-karyanya di bidang sejarah dan ilmu filsafat. Penafsirannya tentang evolusi ilmu pengetahuan dan konsep "pergeseran paradigma" memiliki dampak besar pada pemahaman kita mengenai kehidupan intelektual, baik dalam ilmu fisika ataupun ilmu-ilmu sosial (Van Ness, 2014), termasuk dalam hal ini adalah ilmu HI. Bagian ini akan mengulas secara singkat gagasan Kuhn mengenai paradigma.

Paradigma sebagaimana diketahui adalah sebuah istilah yang pertama kali digunakan oleh Kuhn dalam The Structure of Scientific Revolution (Kuhn, 1989). Apa yang dimaksud dengan paradigma seperti yang dipahami Kuhn, menurut Kuntowijoyo, adalah pada dasarnya realitas sosial itu dikonstruksi oleh mode of thought atau mode of inquiry tertentu, yang pada gilirannya akan menghasilkan mode of knowing tertentu pula (Kuntowijoyo, 2008: 548). Dalam pandangan Immanuel Kant, cara mengetahui itu dianggap sebagai skema konseptual; Marx menamakannya sebagai ideologi; dan Wittgenstein melihatnya

College of Asia and the Pacific, Australian National University, <peter.van-ness@anu. edu.au> 
sebagai cagar bahasa (Kuntowijoyo, 2008: 548).

Secara konseptual paradigma sesungguhnya memiliki bermacam pengertian. Kuhn sendiri, yang memopulerkan istilah itu telah menggunakan 22 pengertian dari konsep tersebut dengan cara yang berbeda. Namun secara umum, Kuhn mengartikan paradigma sebagai model atau pola yang diterima. Paradigma juga dapat berarti apa yang dimiliki bersama oleh anggota-anggota suatu masyarakat ilmiah. Paradigma juga memiliki pengertian keseluruhan konstelasi kepercayaan, nilai, teknik yang dimiliki bersama oleh anggota-anggota masyarakat tertentu dan menunjukkan sejenis unsur dalam konstelasi itu, pemecahan teka-teki konkret yang digunakan sebagai model atau contoh yang kemudian dapat menggantikan kaidah-kaidah yang eksplisit sebagai dasar bagi pemecahan masalah.

Menurut Kuhn, paradigma sebagai model atau pola yang diterima dalam suatu masyarakat ilmiah tertentu dan keberadaannya hanya berlangsung selama masyarakat ilmiah tersebut menerima dan mengakuinya. Jika ditolak, pergantian paradigma menjadi konsekuensi logis perkembangan sains dan pergantian paradigma ini dinamakan sebagai revolusi ilmiah. Rumus perkembangan revolusioner itu dibuat oleh Kuhn berdasarkan kerangka sebagai berikut: Paradigma 1 - Sains Normal - Anomali - Krisis - Paradigma 2 (P1 - SN - A - K - P2).

Bagi Kuhn, kemajuan ilmu pengetahuan akan selalu berawal dari perjuangan kompetitif berbagai teori untuk mendapatkan legitimasi intersubjektif dari satu komunitas ilmu pengetahuan. Teori yang memperoleh legitimasi sosial akan tampil sebagai paradigma (P1). Setelah itu, paradigma ini pun berjalan tanpa tentangan dan ilmu pengetahuan memasuki apa yang disebut oleh Kuhn sebagai Sains Normal (SN).

Namun, Kuhn meyakini bahwa kecenderungan ilmuwan untuk menyingkirkan fakta-fakta (anomali) yang tidak sesuai dengan paradigma dominan yang dianut akan membawa periode SN pada tahap krisis. Krisis ini merupakan akumulasi fakta-fakta anomali yang membuat keabsahan suatu paradigma menjadi goyah. Fakta-fakta anomali ini terkadang muncul secara tiba-tiba dan mengejutkan ilmuwan karena berlawanan sama sekali dengan apa yang seharusnya terjadi menurut paradigma. Misalnya, Kuhn mengemukakan kasus penemuan baterai elektrik yang terjadi tatkala detektor arus statis gagal bekerja seperti apa yang seharusnya terjadi berdasarkan paradigma Franklin. Dengan begitu, paradigma tidak mampu mempertahankan diri karena desakan akumulasi fakta-fakta anomali yang semakin menjadi (Adian, 2002: 88).

Krisis ini memaksa komunitas ilmu pengetahuan mempertanyakan kembali secara radikal dasar-dasar ontologis, metodologis, dan nilai-nilai yang selama ini dipakainya. Karena hal itulah krisis kemudian mendorong lahirnya paradigma baru (P2) yang sama sekali berbeda dengan paradigma sebelumnya (P1) (Adian, 2002: 89).

Dalam ilmu HI, satu hal yang disepakati oleh hampir semua ilmuwannya, baik yang pro ataupun kontra, adalah realisme merupakan satu-satunya pendekatan yang paling pantas mendapat status paradigma ( $\mathrm{P} 1)$ menurut kategori Kuhnian. Seorang pospositivis Colin Wight misalnya, pernah mengakui realisme sebagai calon kuat pendekatan HI yang bisa menjadi paradigma paling dominan dalam ilmu HI (Wight, 2013: 37). Dan para ilmuwan HI telah berulang kali mendefinisikan dan menjalankan asumsiasumsi inti (core as asumptions) dari paradigma realisme (pendefinisian ulang mengenai paradigma realisme akan dikupas setelah bahasan ini).

Akan tetapi, meskipun realisme dinilai sebagai pendekatan terkemuka bagi status paradigma dalam disiplin $\mathrm{HI}$, ia bukanlah calon tunggal paradigma. Para ahli telah menciptakan sejumlah paradigma alternatif, yang hampir selalu didefinisikan bertentangan dengan realisme (Schmidt, 2013: 10). Van Ness adalah salah satu ahli 
yang dimaksud dan gigih dalam menggugat paradigma realisme. Gugatan Van Ness ini menunjukkan seakan-akan realisme sedang memasuki tahap krisis (K) dan lahirlah paradigma baru (P2) yang berbeda sekaligus bertentangan dengan paradigma realisme (P1).

\section{Paradigma Realisme}

Seperti yang pernah dikatakan Francis Fukuyama (2003) bahwa politik dan hubungan internasional adalah masalah evolusi sejarah. Ke arah mana angin sejarah bergerak, di situ kita akan menemukan tekateki sejarah yang kontradiktif dan dialektis. Mereka yang optimis tentang jalannya sejarah dunia tentu akan mengikuti polapola historis yang tergambar dalam tradisi filsafat idealisme Hegel dalam bingkai "Pertempuran Jena",5 sementara bagi mereka yang pesimis, pola-pola historis yang tergambar cenderung mengikuti tradisi filsafat realisme politik Thucydides dalam bingkai "Perang Peloponnesia". ${ }^{6}$ Dengan demikian, perjalanan sejarah dunia adalah perjalanan sejarah yang dialektis, sulit untuk mereka-reka ke arah mana angin sejarah akan bergerak: akankah mengarah pada kemajuan (endisme) atau pada kemunduran (deklinisme).

Teori mainstream dalam ilmu ekonomi dan sosiologi, selama berabadabad yang lalu, telah dan terus berjuang dengan problem sejarah dan perubahan sejarah. Namun, para teoretisi hubungan internasional bertradisi filsafat realisme justru berbicara seolah-olah sejarah tidak eksis, misalnya, seolah-olah perang dan imperialisme adalah aspek permanen dari cakrawala manusia. Sementara seluruh aspek yang lain dari lingkungan sosial manusia seperti agama, keluarga, organisasi

5 "Akhir Sejarah" bagi Hegel terjadi pada 1806. Saat itu Hegel melihat penaklukan monarki Prusia (Jerman) oleh Napoleon dalam Pertempuran Jena sebagai kemenangan cita-cita Revolusi Perancis dan universalisasi bentuk negara yang merangkum asas kebebasan dan persamaan bagi seluruh umat manusia. ekonomi, konsep-konsep mengenai legitimasi politik tunduk pada evolusi sejarah, hubungan internasional justru tidak demikian, sejarah selalu dianggap selamanya identik dengan dirinya sendiri: "Perang adalah Abadi" (Fukuyama, 2003: 374).

Pandangan pesimistis mengenai hubungan internasional ini telah memberi suatu formulasi sistematis yang berjalan dalam berbagai julukan tentang "realisme, real politik, atau politik kekuasaan”. Realisme, baik secara sadar disebut dengan nama itu atau tidak, adalah kerangka yang dominan dalam memahami hubungan internasional, dan secara virtual telah membentuk pemikiran mengenai setiap kebijakan luar negeri profesional saat ini di Amerika Serikat dan tempat-tempat lain di dunia (Fukuyama, 2003: 374), terutama sejak Thucydides, Machiavelli, Hobbes, Carr, Morgenthau, dan Waltz membahas masalah ini di dalam karya-karyanya.

Realisme politik ketika menganalisis hubungan internasional selalu mendasarkan pandangan mereka pada realitas, pada apa yang ada, dan bukan pada apa yang seharusnya, seperti yang diklaim oleh kaum idealisme politik. Di dunia nyata, menurut kaum realis, konflik sudah diambang pintu karena sifat kekerasan yang melekat di dalam diri manusia dan karena jalan yang dipilih oleh penduduk dunia lebih tertarik untuk mengorganisasikan bentuk negara yang berdaulat dan independen yang cenderung tidak menghormati otoritas di luar atau di atas negaranya. Pemikiran kaum realis dengan demikian berlandaskan pada pencarian kekuatan dan dominasi yang berasal dari sifat manusia sebagai alasan dasar bagi konflik (Sorensen, 2003: 205).

\footnotetext{
6 Lain lagi dengan Thucydides. Menurutnya Perang Peloponnesia menandai sejarah gelap manusia. Dalam pengertian realisme politik, Perang Peloponnesia mengindikasikan kehausan manusia pada kekuasaan politik untuk mendominasi lainnya. Itulah mengapa Thucydides mengatakan "Sejarah Gelap Manusia Akan Terus Berulang".
} 
Mereka juga cenderung menjadi determinis dan yakin bahwa ada kekuatankekuatan kausal yang berada di luar kemampuan manusia-ada hukum-hukum obyektif yang menjadikan pola-pola tingkah laku tertentu pasti berlaku, tidak dapat dihindarkan, terutama sekali dalam hubungan internasional. Ini berarti bahwa kaum realis tidak begitu yakin pada kemampuan akal pikiran manusia untuk mencari pemecahan-pemecahan jitu terhadap masalah-masalah yang dihadapinya. Secara demikian realisme politik mengandung unsur-unsur oportunisme dan menekankan pada ekspediensi dalam arti sangat terpengaruh oleh lingkungan yang ada dan mengambil langkah-langkah yang paling pragmatis dalam memecahkan masalah, sungguhpun langkah-langkah itu tidak benar untuk jangka waktu yang panjang.

Realis juga beranggapan bahwa prinsip-prinsip moral tidak dapat diterapkan untuk memahami perilaku politik negara. Sebagaimana yang dinyatakan oleh Morgenthau, bahwa "realisme politik tidak memerlukan pembenaran moral, akan tetapi ia memerlukan pembedaan yang tajam antara apa yang dikehendaki dan apa yang mungkin, antara apa yang diharapkan di mana pun kapan pun" (Morgenthau, 1985: 7). Kalangan realis juga menolak penerapan prinsip-prinsip moral dalam analisis politik internasional karena perbedaan mendasar antara politik internasional dan politik domestik. Di tingkat domestik terdapat otoritas-otoritas berkuasa yang dapat mengatur moralitas individu, sementara di dunia internasional tidak ada otoritas berkuasa yang dapat mengatur kehidupan negara karena hubungan antar negara berlangsung dalam lingkungan yang anarkis.

Karena itulah, seorang yang sangat liberalis pun, seperti Stanley Hoffman, bahkan mengatakan bahwa "dalam suatu masyarakat anarkis dari bangsa-bangsa yang hidup dalam keadaan 'tidak damai' atau 'keadaan perang', semua yang bergantung pada pandangan John Locke ataupun Thomas Hobbes akan melihat hal yang sama ketika dihadapkan pada masalahmasalah dunia. Akan selalu ada yang namanya perasaan ketidakamanan. Tidak semua negara atau pelaku dapat sama-sama aman selama belum tercapai dunia yang bebas dari ancaman dan permusuhan" (Hoffman, dalam Bertram, 1988: 130).

Pertanyaannya adalah, mengapa kaum realis begitu pesimis terhadap kondisi politik internasional? Mengapa kaum realis begitu meyakini ancaman keamanan, konflik, dan anarki menjadi hal yang mutlak dan akan terus berlangsung selama negara masih menjadi unit politik yang independen? Menurut Vioti dan Kauppi, setidaknya ada empat hal pokok yang bisa menjawabnya (Viotti \& Kauppi, 1999: 6-7; dan Andre Pareira, 1999: 102-104). Pertama, negara dipandang sebagai pelaku utama sekaligus pelaku terpenting (state are the principal or most important actors). Dalam asumsi ini, negara dipandang sebagai unit utama dalam analisis, baik ketika orang membahas masyarakat politik zaman Yunani Kuno (polis) maupun analisis masyarakat politik modern (nation state), dan studi HI adalah studi hubungan di antara unit-unit masyarakat politik. Seorang realis yang menggunakan konsep sistem, mendefinisikan terminologi sistem dalam pengertian sistem internasional yang melibatkan negara sebagai elemen-elemen dalam sistem tersebut. Elemen-elemen lain bukan negara di dalam sistem internasional, seperti organisasi internasional, multinational coorperation, transnational groups juga merupakan aktor, tetapi perannya kurang penting dibandingkan negara.

Kedua, negara dipandang sebagai kesatuan aktor (state is viewed as a unitary actor). Untuk tujuan analisis, seorang realis melihat negara ibaratnya sesuatu mahkluk yang terbungkus oleh sel-sel kehidupan yang keras (as being encapsulated by metaphorical hard sell). Sebuah negara berhadapan dengan dunia luar yang juga merupakan suatu unit yang terintegrasi. Dalam pengertian ini negara dilihat sebagai otoritas tertinggi, yang perwujudannya oleh 
pemerintah, dan pemerintah adalah representasi negara yang menyuarakan dengan satu suara yang sama untuk kepentingan negara secara keseluruhan. Sehingga apabila terjadi sesuatu di dalam sistem negara yang berhubungan dengan lingkungan di luar negara, negara (pemerintah) melakukan intervensi untuk mengambil suatu tindakan, peran aktor nonnegara yang berbeda pandangan dengan negara (pemerintah) diarahkan untuk kepentingan kebijaksanaan yang terpusat dan dikontrol oleh negara.

Ketiga, negara secara esensial diasumsikan sebagai aktor yang rasional (state is essentially a rational actor). Asumsi ini berhubungan dengan proses pembuatan keputusan politik luar negeri, yang seharusnya mencakup perumusan tujuan, pertimbangan-pertimbangan alternatif dalam pengertian ketersediaan kapabilitas negara, pertimbangan kemungkinan berbagai macam alternatif yang bisa digunakan dengan disertai pertimbangan keuntungan dan kerugian untuk masing-masing alternatif yang digunakan. Asumsi ini juga memperhitungkan bahwa unsur kemanusiaan dari para pembuat keputusan yang mungkin saja menimbulkan persepsi yang salah tentang lingkungan yang dihadapi yang bisa mengarahkan politik luar negeri tidak sesuai dengan tujuan.

Keempat, keamanan nasional merupakan isu utama dan menempati tempat teratas di samping isu-isu lainnya (national security is on top of the list within the hierarchy of international issue) sehingga aspek militer dan isu-isu politik yang berhubungan dengan masalah keamanan nasional mendominasi perpolitikan dunia. Seorang realis juga biasanya memusatkan perhatiannya pada potensi konflik yang ada di antara aktor negara, dalam rangka memperhatikan atau menjaga stabilitas internasional, mengantisipasi kemungkinan kegagalan upaya penjagaan stabilitas, memperhitungkan manfaat dari tindakan paksaan sebagai salah satu cara pemecahan terhadap perselisihan, dan memberikan perlindungan terhadap tindakan pelanggaran wilayah perbatasan. Oleh karena itu, power adalah konsep kunci. Dalam kacamata realis, keamanan militer dan isu-isu strategis tergolong kepentingan utama dan mengacu pada kategori politik berbobot tinggi (high politics), sedangkan ekonomi dan isu-isu sosial dilihat oleh kaum realis sebagai hal yang biasa, kurang penting atau mempunyai bobot politik yang rendah (low politics).

Meskipun keempat pandangan di atas merupakan prinsip umum dari realisme, namun realisme bukanlah teori tunggal. Realisme dapat dikelompokkan lagi menjadi dua pendekatan, yaitu "realisme klasik" dan "neo-realisme." Tak hanya itu, neo-realisme pun dibagi lagi menjadi dua varian: defensif dan ofensif. Penganut paham realisme klasik seperti Hans J. Morgenthau percaya bahwa negara, seperti halnya manusia, memiliki hasrat yang tak pernah terpuaskan untuk mendominasi yang lainnya dan pada akhirnya membawa mereka pada peperangan.

Sebaliknya, neo-realis defensif yang dimapankan oleh Kenneth Waltz, justru mengabaikan sifat alamiah manusia dan memfokuskan analisisnya pada dampak yang dihasilkan sistem internasional. Bagi Waltz (1979), sistem internasional terdiri dari sejumlah kekuatan besar, yang masingmasing berusaha untuk bertahan karena sistem berjalan secara anarkis (suatu kondisi yang dihasilkan karena tidak adanya otoritas sentral yang dapat mengaturnya). Di dalam kondisi yang anarkis seperti itu, setiap negara akan mempertahankan dirinya sendiri. Untuk itu, kata Waltz, kondisi ini telah memaksa negara-negara lemah menjadi berupaya untuk mengimbangi negara-negara yang kuat. Sejalan dengan Waltz, seorang neo-realis ofensif John J. Mearsheimer (2001), mengatakan bahwa struktur sistemlah yang menentukan bagaimana negara berperilaku, bagaimana cara mereka memandang satu sama lain dan ini bisa berakibat pada apa yang disebut dengan anarki internasional.

Akan tetapi Waltz dan Mearsheimer memiliki perbedaan pandangan dalam 
menjelaskan tujuan negara. Mearsheimer, misalnya, percaya bahwa setiap negara akan berupaya untuk menjadi kekuatan hegemon dan lebih agresif daripada yang dibayangkan oleh Waltz. Tujuan negara menurut Mearsheimer adalah untuk mendominasi seluruh sistem, dan menjadi pihak yang berkuasa di kawasan dunia (Kreisler, 2002).7 Jika anda adalah yang terbesar, tidak akan negara manapun yang berani menentang anda karena anda begitu berkuasa. Ambillah belahan bumi Barat sebagai contoh, di mana AS sejauh ini merupakan negara yang paling berkuasa di kawasan ini. Di kawasan itu, tidak akan ada negara seperti Kanada, Guetamala, Kuba, ataupun Meksiko yang akan berpikir untuk berani melawan atau berperang dengan AS karena kekuatan AS terlalu besar bagi mereka. Berbeda dengan Waltz. Menurutnya, pandangan Mearsheimer itu tidak tepat. Karena dengan menjadi begitu berkuasa, dan ketika suatu negara bergerak ke arah sana, negara lain pasti akan berupaya untuk mengimbangi dan melawannya.

Meski ada perbedaan pandangan dalam hal keutamaan unit analisis dan tujuan negara dari varian-varian realisme di atas, secara prinsip mereka menyepakati satu hal bahwa sistem politik internasional akan selalu berjalan secara anarkis dikarenakan memang tidak adanya otoritas tunggal (baca: LBB atau PBB) yang bisa membuat dunia menjadi jauh lebih harmonis.

\footnotetext{
7 Penting untuk dicatat: agar tidak salah menafsirkan maksud Mearsheimer mengenai tujuan negara untuk mendominasi atau menghegemoni seluruh sistem adalah hanya menjadi "dominan atau hegemon secara regional dan bukan global." Karena menurut Mearsheimer luas dunia terlalu besar dan terdapat proyeksi kekuasaan besar yang dihubungkan dengan perairan yang memisahkan
}

\section{Gugatan Van Ness}

Secara tegas Van Ness menggugat semua pandangan paradigma realisme di atas. Menurut Van Ness, dunia tidak lagi bekerja dalam kerangka pemikiran realis. Karenanya, Van Ness meyakini paradigma realisme sedang mengalami krisis yang disebabkan oleh semakin banyaknya anomali yang dihadapi dunia pada era kekinian: negara-negara kini lebih memilih strategi win-win daripada strategi zerosum dalam menyelesaikan perselisihan; negara-negara juga saat ini telah menunjukkan keharmonisannya karena mereka merasa saling membutuhkan dan tergantung satu sama lain; dan yang paling penting menurut Van Ness adalah kegagalan realisme untuk memberikan penjelasan tentang munculnya pendekatan "Kerjasama Keamanan."

Untuk yang pertama, Van Ness mengambil contoh kasus senjata nuklir. Hampir semua negara paling kuat di dunia, kecuali Jerman dan Jepang (dua negara yang dikalahkan dalam Perang Dunia Kedua), memiliki senjata nuklir. Menurut Van Ness, perang besar di antara mereka sangat tidak mungkin terjadi dilihat dari alasan atau perspektif rasional manapun. Mengapa demikian? Karena perang nuklir pastinya tidak akan dimenangkan oleh pihak manapun dan perang ini hanya akan menjadi ajang bunuh diri masal di antara mereka. Fakta ini, Van Ness kembali mengutarakan, telah menyadarkan para pembuat kebijakan luar negeri Amerika

berbagai kawasan di seluruh dunia. Dengan kata lain, AS tidak akan mungkin memerangi Asia dan menaklukan sebagian besar wilayah Asia. Jika ingin melakukan penaklukan semacam itu, AS harus melibatkan proyeksi kekuasaan di seluruh parit raksasa yang disebut Samudera Pasifik dan hal itu tentunya tidak akan mungkin terjadi. 
Serikat dan Uni Soviet ketika terjadinya krisis rudal Kuba pada 1962. Padahal waktu itu mereka berada di ambang bencana perang nuklir. Oleh karena itu, kedua negara superpower tersebut kini lebih memilih bekerjasama dalam pengendalian senjata yang dirancang untuk membatasi bahaya senjata nuklir. ${ }^{8}$

Van Ness meyakini bahwa pengalaman krisis rudal Kuba menunjukkan tidak ada definisi yang masuk akal mengenai "kepentingan nasional" dari negara besar pemilik senjata nuklir (AS, Russia, dan China) yang bisa membenarkan sebuah kebijakan untuk saling memerangi satu sama lain. Dengan demikian, tidak mungkin bagi AS dan China berperang untuk kasus Taiwan atau berperang untuk memperebutkan pulau di Laut Cina Selatan dengan menggunakan senjata nuklir.

Selain soal nuklir, Van Ness juga melihat terjadinya krisis paradigma realisme oleh karena adanya saling ketergantungan dalam hubungan antar negara. Sebagai contoh, Anda tidak bisa berhasil dalam membangun perjanjian perdagangan bebas dengan menerapkan strategi zero-sum karena negara-negara lain tentunya tidak akan ikut untuk bergabung. Rangsangan agar banyak pihak bisa berpartisipasi dalam perdagangan internasional adalah dengan strategi winwin. Contoh lain yang juga menurut Van Ness bisa menggeser paradigma realisme ini terkait dengan adanya masalah pada konsep kemandirian. AS, misalnya, tidak akan bisa menghadapi krisis keuangan 2008 jika berpegang pada kemandirian (self-help). Washington harus mendapatkan banyak bantuan dari rekan-rekannya di OECD, dan meraih kerjasama sebanyak mungkin dengan China, agar bisa menghindari terjadinya depresi global.

8 Menurut catatan penulis, sejak tahun 1968-2002, setidaknya terdapat 9 perjanjian yang telah disepakati oleh Amerika Serikat dan Uni Soviet/Rusia untuk melakukan pengawasan dan pelucutan senjata, antara lain Nonproliferation Treaty (1968), Outer Space Treaty (1967), Strategic Arms Limitation Talk I (1972), Antiballistic
Untuk itu, Van Ness menawarkan paradigma alternatif hubungan internasional mengenai "kerjasama keamanan" yang menurutnya bisa menjelaskan perkembangan internasional secara lebih baik daripada paradigma realisme. Paradigma "kerjasama keamanan" ini menurut Van Ness bisa menjelaskan sejumlah anomali dari paradigma realis, seperti perubahan iklim, proliferasi nuklir, pembangunan berkelanjutan, dan manajemen krisis ekonomi global.

Pendekatan "kerjasama keamanan" ini lebih menyerukan negara-negara untuk membangun hubungan yang saling menguntungkan dengan musuh-musuh potensialnya, daripada berinvestasi untuk persiapan-persiapan militer yang akan digunakan untuk memerangi mereka. Asumsi dasar yang menggarisbawahi pendekatan alternatif ala Van Ness ini adalah persepsi ancaman telah berubah. Jika kaum tradisional berfokus pada ancaman militer, pendekatan di era kekinian lebih cenderung kepada kerjasama keamanan.

Dalam hubungannya dengan keamanan ekonomi, misalnya, anarki tidak lagi menjadi pilihan karena saat ini negaranegara telah menjadi tergantung satu sama lain. Van Ness juga menyebut contoh mengenai kesehatan publik-bagaimana sebuah negara secara sendirian dapat melindungi warga negaranya dari penyakit pandemik seperti flu burung $\mathrm{H}_{5} \mathrm{~N}_{1}$ (atau kini $\mathrm{H}_{7} \mathrm{N9}$ )? Perlawanan terhadap terorisme juga merupakan contoh lain yang disebutkan Van Ness. Van Ness juga menunjuk pada pencarian kelangsungan energi. Meski pencarian energi bisa menyebabkan persaingan dan mungkin konfrontasi antarnegara, namun dalam banyak kasus, Van Ness meyakini pemerintah negaranegara justru menitikberatkan pada kerjasama yang lebih bermanfaat.

Missile Treaty (1972), Strategic Arms Limitation Talk II (1979), Intermediate Range Nuclear Forces Treaty (1987), Strategic Arms Reduction Talks I (1991), Strategic Arms Reduction Talks II (1993), Comprehensive Test Ban Treaty (1996), dan Strategic Offensive Reduction Treaty (2002). 
Diakhir bahasannya mengenai kerjasama keamanan, Van Ness juga memberikan contoh lainnya pada pidato presiden Susilo Bambang Yudhoyono (SBY) dalam Shangri-La Dialogue, 1 Juni 2012. Menurut Van Ness, Presiden SBY telah memberikan contoh bagus tentang apa yang dimaksud dengan Kerjasama Keamanan. Saat itu tema yang diangkat SBY adalah "kerjasama geopolitik". Dengan membandingkan sejarah masa lalu kesepuluh anggota ASEAN dengan masa kini, SBY mengatakan bahwa:

"There is no war in Southeast Asia and, in contrast with the past, ASEAN states are in charge of regional affairs. Trade barriers between ASEAN states are down, and connectivity is increasing. We have decisively moved on from a region of conflict and division, to a region of peace, progress and cooperation."

SBY juga menambahkan bahwa "untuk pertama kalinya dalam sejarah, hubungan antara kekuatan-kekuatan besar juga berjalan dengan penuh perdamaian, kestabilan dan saling bekerjasama." Untuk itu, SBY kembali mengutarakan bahwa:

"We have the opportunity to build a durable architecture for peace in our region. This architecture can be more durable, and more peaceful, than at any regional order in previous decades or centuries ... Both the US and China have an obligation not just to themselves, but to the rest of the region to develop peaceful cooperation ... the relations of major powers are not entirely up to them. Middle and smaller powers too can help lock the major powers into this durable architecture."

Asumsi dasar yang menggarisbawahi paradigma alternatif Van Ness ini adalah pemahaman tentang keamanan negara telah berubah. Bila dulu kaum tradisional realis berfokus pada ancaman keamanan, kini negara-negara lebih tertarik pada kerjasama keamanan.

\section{Pembelaan Realis}

Pada bagian ini, penulis akan membahas pembelaan realis atas gugatan Van Ness. Penulis akan memberikan sejumlah contoh kasus empiris yang jauh lebih kuat secara argumen dari Van Ness.

Sebagaimana diketahui, realisme adalah suatu upaya untuk menggambarkan situasi politik internasional itu berjalan secara anarkis. Dalam gejala ilmu sosial mungkin saja terjadi suatu anomali seperti yang telah disinggung oleh Van Ness, dimana politik internasional ternyata berjalan dengan aman tanpa adanya ketegangan, konflik, ataupun perang. Dengan begitu realisme patut dipertanyakan keabsahan paradigmanya. Namun, seperti ditunjukkan oleh Kuhn, kejadian-kejadian yang menyimpang (anomali) ini tak serta merta bisa menggugurkan suatu paradigma (Huntington, 1993: 187). Ketika Perang Dingin berakhir kita mendapati bahwa situasi politik internasional tetap berjalan secara anarkis. Prediksi paradigma endisme tentang perdamaian di era Pasca Perang Dingin ternyata salah. Krisis Teluk yang berujung pada invasi Amerika Serikat terhadap Irak adalah bukti nyata kegagalan paradigma endisme mempediksi situasi politik internasional.

Dengan begitu dapat dikatakan bahwa berakhirnya Perang Dingin, struktur dasar sistem internasional sebagian besar tidak mengalami perubahan. Negara masih menjadi aktor penting politik internasional dan terus bekerja dalam sistem yang anarkis. Sangat sulit untuk menemukan seorang ahli yang berani mengatakan bahwa PBB atau institusi internasional lainnya dapat memaksakan pengaruhnya terhadap negara-negara berkekuatan besar atau memungkinkan untuk dapat memiliki pengaruh tersebut di masa yang akan datang (Mearsheimer, 1994/95: 549), karena kedaulatan negara belum juga berakhir.

Apabila sistem internasional tidak mengalami perubahan selama tahun 1990, kita tidak dapat berharap bahwa perilaku negara di abad baru ini akan jauh berbeda dari apa yang berlaku di abad sebelumnya. Pada kenyataannya, terdapat bukti berlimpah yang 
menunjukkan bahwa negara masih memperjuangkan kekuasaan dan siap berkompetisi untuk mendapatkan kekuasaan tersebut di masa yang akan datang. Sejarah juga masih memperlihatkan bahwa kompetisi memperjuangkan kekuasaan bisa menjerumuskan negara pada perang dan tidak berhenti meski Uni Soviet runtuh.

Amerika Serikat, misalnya, tercatat telah melakukan peperangan dengan dua negara yang relatif lebih lemah sejak akhir Perang Dingin, yaitu dengan Irak (1991) dan Kosovo (1999). AS juga hampir saja berperang dengan Korea Utara (Korut) pada 1994. Bahkan kedua kandidat presiden (George W. Bush dari Republik dan Al Gore dari Demokrat) pada kampanye presiden tahun 2000 telah merencanakan untuk menghabiskan lebih banyak anggaran negara untuk Pentagon. Jadi, tidak ada alasan bagi ilmuwan penentang realis untuk mengatakan bahwa negara tidak lagi peduli tentang keamanan mereka (Mearsheimer dalam Brecher \& Harvey, 2002: 26). 9

Selain itu, wilayah Asia Selatan dan Teluk Persia adalah contoh bagus pembelaan realis. Di wilayah Asia Selatan, terdapat bom yang sewaktu-waktu bisa meledak karena potensi konflik antara India dan Pakistan sangat sulit untuk didamaikan. Celakanya, kedua negara ini dipersenjatai dengan senjata nuklir, serta memungkinkan keduanya untuk saling berperang dalam persoalan klaim atas Kashmir. Di Teluk Persia juga terdapat potensi konflik dengan makin seriusnya Iran dalam mengembangkan senjata nuklir. Dua kasus ini menjadi bukti nyata masih terdapatnya ancaman keamanan (Mearsheimer dalam Brecher \& Harvey, 2002: 26-27).

Demikian halnya dengan wilayah Asia Timur Laut (NEAsia) dan Eropa. Anggapan yang mengatakan bahwa kedua kawasan tersebut adalah contoh terbaik tentang tidak adanya konflik merupakan argumen yang lemah. Terdapat sejumlah literatur yang mengkaji tentang keamanan NEAsia di era pasca Perang Dingin dan hampir setiap penulis

${ }_{9}$ Penting untuk dicatat sebagian contoh anarki dalam bahasan berikut kebanyakan mengutip langsung dari tulisan John Mearsheimer. Namun untuk setiap data yang mengakui bahwa kekuasaan politik tetap hidup di kawasan tersebut. Pemerintah Jepang, misalnya, mempersepsikan bahwa jika ekonomi dan politik China terus berkembang selama beberapa dekade ke depan, mungkin kompetisi keamanan di kawasan ini akan semakin membahayakan, khususnya bagi China dan negara tetangganya, termasuk AS. Bahkan Thomas J. Christensen (1996: 37) menyebut China sebagai, "the high church of realpolitic in the post-cold war". Satu lagi bukti terbaik bahwa kekuasaan politik masih relevan di kawasan NEAsia adalah AS telah mengirimkan seratus ribu pasukan di kawasan ini dan berencana menempatkan pasukan tersebut untuk jangka waktu yang lama. Jika NEAsia adalah zona perdamaian, pasukan AS seharusnya tidak perlu lagi ditempatkan di sana, dikirim pulang, dan dimobilisasikan untuk menghemat pajak yang dibayar oleh masyarakat AS. Singkatnya, NEAsia tetap merupakan kawasan yang secara potensial berbahaya, di mana kompetisi keamanan di kawasan ini tetap merupakan masalah serius dalam politik internasional.

Joseph Nye (1990: 90-102), arsitek utama kebijakan luar negeri AS di NEAsia pada era pasca Perang Dingin dan seorang ahli hubungan internasional dengan reputasi mapan menyatakan, "it has become fashionable, to say that the world after the Cold war has moved beyond the age of power politics to the age of geoeconomic". Pernyataan Nye ini menurut Mearsheimer adalah sebuah ilusi, dan mencerminkan analisa yang sempit. Bagi Mearsheimer, politik dan ekonomi saling berkait, sistem ekonomi internasional akan selalu bersandar pada tatanan politik internasional. Kolega Nye, Robert Keohane pada 1984 juga mengatakan hal yang serupa dengan Mearsheimer, "Di dalam perekonomian dunia, kapan pun juga, para pelakunya akan menggunakan kekuasaan untuk saling memberikan pengaruh satu sama lain agar dapat mencapai tujuannya masingmasing. Hal inilah yang membuat ekonomi internasional sarat dengan muatan politis"

penulis miliki, catatan perut tidak ditulis berdasarkan sumber yg dikutip dari Mearsheimer, melainkan dari sumber tulisan yang asli. 
(Keohane, 1984: 21). Begitu pula dengan asumsi Kenneth Waltz, bahwa di dalam dunia yang sangat realis, distribusi ekonomi antarnegara yang dihasilkan dari kerjasama ekonomi internasional apapun, tidaklah dibagi berdasarkan keuntungan bagi semua pihak, tetapi siapa yang akan mendapatkan untung lebih banyak di dalam perdagangan internasional,

"inequality in the expected distribution of the increased product works strongly against the extension of the division of labor internationally. When faced with the possibility of cooperating for mutual gain, states that feel insecure must ask how the gain will be divided. They are compelled to ask not 'will both of us gain' but 'who will gain more?" (Waltz, 1979: 105).10

Begitu pula dengan kawasan Eropa. Beberapa penulis percaya bahwa kawasan Eropa adalah tempat yang tidak lagi terkontaminasi dengan praktek "Power Politics" di antara kekuatan-kekuatan besar, terutama dengan berkembangnya keyakinan yang meluas di awal tahun 1990 bahwa Rusia telah menjalani transformasi besar dalam pemikirannya tentang politik internasional. Banyak elit di Rusia yang meyakini dan memahami bahwa kompetisi kekuasaan tidak mungkin lagi dapat memperkuat dan melindungi negaranya, dan cara terbaik untuk mencapai tujuan tersebut adalah dengan meningkatkan kerjasama dengan negaranegara Barat dalam menciptakan tatanan yang jauh lebih aman dan damai di seluruh kawasan Eropa. Beberapa pendapat lain juga menyebutkan bahwa di era pasca Perang Dingin, Eropa Barat telah menyediakan fondasi bagi tatanan politik yang lebih stabil di seluruh daratan Eropa (Mearsheimer dalam Brecher \& Harvey, 2002: 28).

Namun pada kenyataannya, banyak halhal yang tidak bekerja sebagaimana mestinya di kawasan Eropa. NATO, misalnya, hanya

${ }^{10}$ Yang dimaksud oleh Waltz tentang hal ini adalah upayanya untuk mengkritik asumsi kaum liberalis yang mengatakan bahwa kerjasama ekonomi internasional akan memberikan situasi stabil pada separuh bagian Barat daratan ini. Ekspansi NATO ke Timur telah membuat marah Rusia, yang kini kembali berpikir dengan cara-cara lama (realis). Untuk merespons sikap NATO tersebut, Presiden Vladimir Putin dalam "The National Security Concept of the Russian Federation" (http://www.armscontrol.org/act/2000_0102/docjfoo), sebuah dokumen kebijakan luar negeri Rusia yang ditandatangani pada 10 Januari 2000, menyatakan,

"the formations of international relations is accompanied by competition and also by the aspiration of a number of states to strengthen their influence on global politics, including by creating weapons of mass destruction. Military force and violence remain substantial aspects of international relations".

Sama seperti di NEAsia, mungkin bukti terbaik bahwa praktik politik kekuasaan tidak hilang di Eropa adalah tentang penempatan seratus ribu pasukan AS dalam NATO. Jika Eropa memang merupakan "zona perdamaian", NATO seharusnya dibubarkan dan pasukan Amerika dapat dimobilisasi dan ditarik pulang. Tetapi yang terjadi justru sebaliknya, mereka tetap dipertahankan, karena memang terdapat potensi kompetisi keamanan di wilayah Eropa. Jika tidak, mengapa Washington menghabiskan sepuluh juta dollar setiap tahunnya untuk membangun keberadaan militernya di Eropa? (Mearsheimer dalam Brecher \& Harvey, 2002: 28).

Dalam suatu survei yang dilakukan oleh Robert Art antara tahun 1990 dan 1994 dengan mewawancarai lebih dari seratus elit politik dan militer Eropa, telah diketahui bahwa banyak orang Eropa yang percaya bahwa AS merahasiakan kompetisi keamanan di kawasan mereka. Dalam penelitiannya ini, Art menemukan banyak di antara mereka yang menyatakan, "If the Americans removed their security blanket from Europe... the Western

meningkatkan interdependensi ekonomi antara Negara, dengan kata lain keuntungan bagi semua Negara. 
European states could well return to the destructive power politics that they had just spent the last forty-five years trying to banish from their part of the continent" (Art, 1996: 5$6)$.

Christoph Bertram, mantan Direktur IISS (International Institut for Strategic Studies) di London dan salah satu pemikir strategi Jerman, menguatkan argumen tersebut ketika ia menulis pada 1995, "membubarkan NATO pada saat ini justru akan menjatuhkan Eropa ke dalam ketidakamanan... hal ini akan menjadi bencana strategis bagi Eropa... jika AS menarik diri dari Eropa, NATO akan runtuh dan Uni Eropa akan mengalami disintegrasi. Jerman akan berdiri sebagai kekuatan dominan di wilayah Barat, sementara Rusia menjadi kekuatan pengganggu di wilayah Timur. Dengan begitu, AS akan kehilangan otoritas internasionalnya" (Mearsheimer dalam Brecher \& Harvey, 2002: 29).

Tak ketinggalan Barry Posen (1993) juga mengokohkan paradigma realisme. Posen bahkan menawarkan penjelasan baru tentang konflik etnik di Yugoslavia pada era pasca Perang Dingin. Menurutnya, perpecahan negara multietnis akan menempatkan kelompok etnik yang menjadi musuhnya ke dalam lingkungan anarki, hal ini kemudian memicu ketakutan yang terus berkembang dan mendorong tiap kelompok etnik menggunakan kekuatan mereka dalam rangka untuk meningkatkan posisi relatifnya. Hal seperti ini terjadi di Yugoslavia, dimana masing-masing etnik terdorong untuk melakukan "pembersihan etnis" terhadap musuhnya.

\section{Dunia Masa Kini}

Sebagai tambahan atas contoh kasus empiris sebelumnya, penulis juga akan menggambarkan situasi anarkis yang mengancam dunia pada masa kini. Terdapat tiga contoh kasus yang dapat dijadikan tolak ukur untuk menilai adanya anarkisme internasional di era kekinian.

Contoh kasus pertama adalah latihan perang gabungan antara Rusia-Cina selama enam hari di Laut Kuning, sebelah Timur Pantai Cina, pada 22 April 2012. Latihan perang ini tergolong paling besar, yang melibatkan kedua negara. Tidak tanggungtanggung, dalam latihan ini Beijing mengerahkan 4.000 tentaranya, 16 kapal yang terdiri dari lima kapal perusak, lima fregat, empat kapal perang, 1 kapal pendukung, dan satu kapal yang berfungsi sebagai rumah sakit. Selain itu, Beijing juga menurunkan 13 pesawat tempur dan 5 helikopter pengangkut. Sementara dari pihak Moscow mengerahkan empat kapal perang yang terdiri atas kapal penjelajah kelas Slava dan Varyag. Juga tiga kapal perusak kelas Udaloy ditambah dengan tiga kapal pendukung (Asrudin, 2012).

Menariknya adalah, latihan perang ini dilakukan sepekan setelah AS dan Filipina memulai latihan perang di Laut Cina Selatan. Tidak hanya itu, banyak analis yang mengatakan latihan perang Rusia-Cina disebut sebagai bentuk provokasi atas latihan perang yang kebetulan dilakukan secara bersamaan oleh Korea Selatan (Korsel) dan AS (Asrudin, 2012).

Contoh kasus kedua adalah tentang rencana Rusia yang akan menghancurkan sistem pertahanan misil Eropa yang dibentuk oleh AS karena mengancam fasilitas nuklir miliknya. Sebagaimana diketahui rencana pertahanan rudal AS di Eropa telah menjadi salah satu topik yang paling sulit diselesaikan dalam hubungan AS-Rusia selama bertahuntahun (Asrudin, 2012).

Terkait dengan hal itu, pada 4 Mei 2012, Kepala Staf Umum Rusia Nikolai Makarov mengatakan, keputusan untuk menggunakan kekuatan destruktif akan diambil jika situasi terus memburuk. Celakanya, AS justru menyikapi ancaman tersebut dengan akan tetap membangun sistem pertahanan itu meski Rusia menolaknya. Hal ini diperburuk dengan keengganan AS untuk memberikan jaminan keamanan tertulis kepada Rusia bila misilmisil itu tidak ditujukan ke Rusia (Asrudin, 2012).

Sementara itu kasus ketiga yang juga tak kalah penting dan bisa dijadikan sebagai contoh untuk menilai apakah paradigma realisme masih relevan digunakan sebagai pisau analisis dalam membaca masalahmasalah internasional kekinian adalah mengenai penempatan kekuatan militer AS 
dalam jumlah yang sangat besar di kawasan Asia Pasifik. Dalam kunjungan pertamanya ke Indonesia (8-10 Februari 2013), Panglima Komando Militer AS yang ditugaskan Obama di Kawasan Pasifik (PACOM), Laksamana Samuel J. Locklear III menjelaskan mengapa Asia Pasifik kini makin strategis bagi AS di tengah perubahan dinamika kekuatan global (Asrudin, 2013: 4).

Menurut Locklear mengapa penempatan kekuatan militer AS sekarang terfokus di Asia Pasifik, adalah untuk "Rebalance Peran AS di Asia Pasifik." Locklear mengatakan perimbangan itu bukan hanya menyangkut militer saja, tetapi juga kebijakan, diplomasi, dan perdagangan ekonomi. Untuk memuluskan rebalance yang dimaksud, AS mengerahkan lebih dari setengah kekuatan militer laut yang kini ditugaskan beroperasi di kawasan Asia Pasifik. PACOM dibekali setidaknya seperlima dari total kekuatan militer AS dan akan memimpin 60 persen dari armada Angkatan Laut Amerika. Saat ini, armada militer AS di Pasifik diperkuat oleh lima kapal induk dengan kekuatan pendukung, yaitu 180 kapal, 1.500 pesawat, dan 100.000 personel militer aktif (Asrudin, 2013: 4).

Tentu saja pengerahan kekuatan militer ini dilakukan untuk mengamankan kepentingan ekonomi AS di Asia Pasifik, sebuah kawasan yang memiliki dua dari tiga ekonomi terbesar di dunia. Begitu pula dari segi bisnis dan perdagangan, kawasan ini sangat strategis bagi AS. Asia Pasifik, kata Locklear, yang memiliki sembilan dari 10 pelabuhan terbesar di dunia, merupakan jalurjalur laut paling sibuk yang menghasilkan lebih dari US $\$ 8$ triliun, dan 70 persen dari kapalkapal pengangkut bahan energi melintasi lautan Pasifik setiap harinya. Dari sisi pertahanan dan keamanan pun, Asia Pasifik tidak kalah strategis mengingat tujuh dari 10 kekuatan militer terbesar dunia ada di

${ }^{11}$ Meski Kuhn dalam bukunya juga menyinggung istilah incomensurability, dimana setiap paradigma tidak bisa diperbandingkan satu sama lain, namun menggunakan argumen ini hanya akan membuat pendukung paradigma yang berbeda benar-benar tinggal di dunia yang berbeda. kawasan ini, termasuk angkatan-angkatan laut dengan teknologi paling canggih (Asrudin, 2013: 4).

Di tengah resesi ekonomi yang belum juga usai, AS tentu berkepentingan untuk memerluas peranannya di Asia Pasifik. Kawasan itu sangat penting bagi masa depan ekonomi AS, sehingga AS akan terus berjuang menjadi kekuatan utama di Asia Pasifik. Itulah sebabnya AS mendirikan pangkalan militer dan menempatkan pasukan marinirnya di Darwin, Australia (Asrudin, 2011).

Sebagaimana diketahui, penempatan pasukan marinir AS di Darwin ini adalah yang ketiga di kawasan Asia Pasifik setelah di Guam dan Okinawa, Jepang. Secara geografis, ketiga kawasan tersebut rupanya melingkari wilayah China. Itu artinya ada upaya dari Obama untuk melakukan politik pembendungan terhadap China yang dinilai kian agresif di kawasan Asia Pasifik (Asrudin, 2011).

Yang pasti, ketiga contoh kasus ini cukup untuk menunjukkan bahwa anarki masih menjadi bingkai hiasan dunia, sebagaimana yang selama ini diyakini oleh kaum realis.

\section{Penutup}

Berdasarkan uraian di atas, apa yang digugat oleh Van Ness tidak lebih hanyalah sebuah retorika akademis belakakarena Van Ness mengabaikan sejumlah contoh kasus yang telah penulis jabarkan. Itu artinya, walaupun realisme tetap banyak ditentang, bukan berarti pendekatan ini dengan serta-merta menjadi goyah dan tak layak mendapatkan status sebagai paradigma dalam kategori Kuhnian. ${ }^{11}$

Oleh karena itu, mengingat dunia masih bekerja dengan cara-cara realis, Indonesia di era pemerintahan Jokowi dituntut untuk mawas diri dalam merespons isu-isu internasional dan tidak mengulangi

Itu artinya, tidak ada gunanya lagi mencoba mengkritik dunia yang satu dari dunia yang lain (Wight, 2013: 37). Itulah sebabnya penulis menolak argumen incomensurability Kuhnian. 
kesalahan pemerintahan SBY yang terpenjara oleh doktrin a million friends, zero enemy.

\section{Daftar Pustaka}

\section{Buku}

Adian, D.G. (2002) Menyoal Objektivisme Ilmu Pengetahuan: Dari David Hume Sampai Thomas Kuhn. Jakarta: Teraju.

Asrudin. (2009) Teori Perdamaian Demokrasi dalam Hubungan Internasional. Dalam: Asrudin dan Mirza, J.S.eds. Refleksi Teori Hubungan Internasional: dari Tradisional ke Kontemporer. Yogyakarta: Graha Ilmu.

Hoffman, S. (1988) Keamanan dalam Zaman Bergolak: Alat-Alat Respon. Dalam: Bertram C.ed. Konflik Dunia Ketiga dan Keamanan Dunia. Jakarta: Bina Aksara.

Fukuyama, F. (2003) The End of History and the Last Man. Yogyakarta: Qalam.

Keohane, R. (1984) After Hegemony: Cooperation and Discord in the World Political Economy. Princeton: Princeton University Press.

Kuhn, T.S. (1989) Peran Paradigma Dalam Revolusi Sains. Bandung: Remadja Karya.

Kuntowijoyo. (2008) Paradigma Islam: Interpretasi untuk Aksi. Bandung: Mizan.

Mearsheimer, J.J. (2001) The Tragedy of Great Power Politics. New York: W.W Norton.

. (2002) Realism, the Real World, and the Academy. Dalam: Brecher M. \& Harvey, F.P.eds. Realism and Institutionalism in International Studies. Ann Arbor: The University of Michigan Press.

Morgenthau, H.J. (1985) Politics Among Nations: The Struggle for Power and Peace. New York: Alfre A. Knopf.

Pareira, A.H. (1999) Negara dalam Studi Hubungan Internasional: Perubahan dan Kesinambungan. Dalam: Pareira, A.H.ed. Perubahan Global dan Perkembangan Studi Hubungan
Internasional. Bandung: PT. Citra Aditya Bakti.

Schmidt, B.C. (2013) On the History and Historiography of International Relations. Dalam: Carlsnaes W, Risse T, \& Simmons, B.A.eds. Handbook of International Relations. London: SAGE Publications.

Sorensen, G. (2003) Demokrasi dan Demokratisasi: Proses dan Prospek dalam Sebuah Dunia Yang Sedang Berubah. Yogyakarta: CCSS \& Pustaka Pelajar.

Viotti, P.R. \& Mark V.K. (1999) International Relation Theory: Realism, Pluralism, Globalism, and Beyond. Boston and London, Ally and Bacon.

Waltz, K. (1979) Theory of International Politics. New York: Mcgraw Hill.

Wight, C. (2013) Philosophy of Social Science and International Relations. Dalam: Walter C, Thomas R, \& Beth A.S.eds. Handbook of International Relations. London: SAGE Publications.

\section{Jurnal}

Art, R. (1996) Why Western Europe Needs the US and NATO. Political Science Quarterly, 111 (1).

Asrudin. (2010) Memahami Visi Perdamaian Abadi Immanuel Kant. Jurnal Ilmiah Hubungan Internasional, 6 (1).

Christensen, T.J. (1996) Chinese Realpolitik. Foreign Affairs, 75 (5).

Doyle, M.W. (1983) Kant, Liberal Legacies, and Foreign Affairs. Philosophy and Public Affairs, 12 (3).

Huntington, S.P. (1993) If Not Civilizations, What?. Foreign Affairs, 72 (5).

Mearsheimer, J.J. (1994/95) The False Promise of International Institutions. International Security, 19 (3).

Nye, J. (1990) East Asia Security: The Case for Deep Engagement. Foreign Affairs, 74 (4).

Posen, B. (1993) The Security Dillema and Ethnic Conflict. Survival. 
Asrudin. (2011) Mencermati Politik Luar Negeri Obama di Pasifik. Koran Tempo, 23 November.

9 Mei, hal. 7.

. (2012) Perang Dingin Baru. Kompas, . (2013) Merkantilisme Obama. Sinar

Harapan, 21 Februari 2013, hal. 4.

\section{Internet}

Huntington, S.P. (1989) No Exit: The Errors of Endism. The National Interest.[Online]. Tersedia dalam: $<$ http://www.wesjones.com/eoh_noexi t.htm> [Diakses 5 Maret 2007].

Kreisler, H. (2002) Conversations with John J. Mearsheimer: Through the Realist Lens [Online]. Institute of International Studies, UC Berkeley. Tersedia dalam:
$<$ http://globetrotter.berkeley.edu/peop le2/Mearsheimer/mearsheim ercon2.html> [Diakses 10 september 2008].

Russia's National Security Concept [Online]. Tersedia dalam: <http://www.armscontrol.org/act/200 o_01-02/docjfoo> [Diakses 15 Juni 2010].

Van Ness, P. (2014) Thomas Kuhn and International Relations Theory: Realism in Crisis [Online]. Tersedia dalam: $<$ http://ips.cap.anu.edu.au/sites/defaul t/files/14-1.pdf $>$ [Diakses 3 September 2014]. 